\title{
Minimal intervention dentistry: part 5. Ultra-conservative approach to the treatment of erosive and abrasive lesions
}

IN BRIEF

- Stresses the importance of a conservative approach to the treatment of erosive and abrasive lesions.

- Explains how to plan an initial therapeutic approach.

- Suggests there is no unique solution and treatment plans must be made on a case by case basis.

\author{
P. Colon ${ }^{* 1}$ and A. Lussi
}

The therapeutic management of tooth wear lesions does not require the removal of diseased tissue. Nevertheless, diverse etiological factors may be associated with the condition and they could be difficult to eliminate; this has to be considered when planning therapy. Interceptive procedures should be reserved for such situations while regular monitoring is recommended for other cases, in accordance with advice provided for using the Basic Erosive Wear Examination (BEWE). Direct and indirect adhesive procedures with composite resins allow treatment of most clinical situations, including even extensive restorations. The possibility of managing subsequent interventions should be considered when planning the initial therapeutic approach.

\section{INTRODUCTION}

Tooth wear lesions result from chronic attacks on dental tissues without bacterial involvement. This process can involve attack from acids (erosions) or by mechanical

\section{MINIMAL INTERVENTION DENTISTRY II}

1. Contribution of the operating microscope to dentistry

2. Management of caries and periodontal risks in general dental practice

3. Management of non-cavitated (initial) occlusal caries lesions - non-invasive approaches through remineralisation and therapeutic sealants

4. Minimal intervention techniques of preparation and adhesive restorations. The contribution of the sono-abrasive techniques

5. Ultra-conservative approach to the treatment of erosive and abrasive lesions

6. Microscope and microsurgical techniques in periodontics

7. Minimal intervention in cariology: the role of glass-ionomer cements in the preservation of tooth structures against caries

8. Biotherapies for the dental pulp

This paper is adapted from: Colon P, Lussi A. Approche thes Réalités Cliniques 2012; 23: 213-222.

'Université Paris Diderot, Service d'Odontologie, Hôpital Rothschild, AP-HP, Paris, France: ${ }^{2}$ Zahnerhaltung,

Präventiv- und Kinderzahnmedicizin, Zahnmedizinische Kliniken der Universität, Bern, Switzerland

*Correspondence to: Professor Pierre Colon

Email: pierre.colon@univ-paris-diderot.fr

\section{Refereed Paper}

Accepted 15 November 2013

DOI: $10.1038 / \mathrm{sj}$. bdj.2014.328

${ }^{\circ}$ British Dental Journal 2014; 216: 463-468 rubbing of an external element such as a toothbrush or other aggressive agents. It can also be due to simple teeth to teeth contact between occlusal or proximal surfaces and is called attrition. ${ }^{1,2}$

The increasing prevalence of these lesions has been demonstrated by recent studies. ${ }^{3,4}$

These three aetiological processes of erosion, abrasion and attrition give rise to extremely variable clinical situations. This can also result in other diverse clinical features when these three processes are combined. These lesions show three specific features:

- Absence of dental, diseased tissue requiring removal as is the case in dental caries disease

- Loss of dental tissues are also a consequence of physiological wear such as daily acid exposure, toothbrushing and interdental contact. In certain cases, the distinction between physiological and pathological can be difficult to determine

- The aetiological factors are sometimes difficult to control and impossible to eliminate as they result at the same time from normal physiological function.

Consequently its mostly adverse pathological effects on the pulp can result in invasive treatments, whereas totally non-invasive restoration treatments should be recommended in the large majority of clinical situations.

Nevertheless, even with minimal loss of substance, this process will continue if the aetiological factors have not been

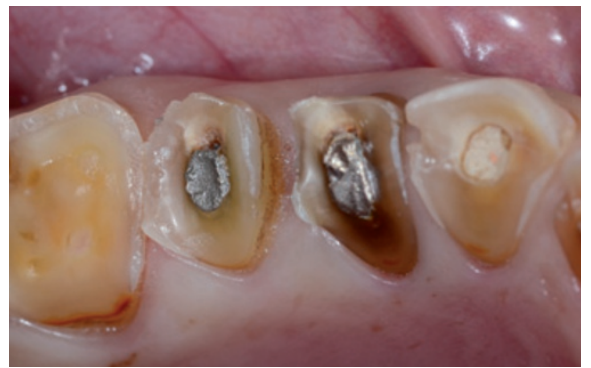

Fig. 1 Erosive and abrasive lesions could lead to considerable defects. Here is the clinical case of a woman, 35 years old, with anorexia and bulimia when she presented to the consultation

eliminated, requiring complex rebuilding of the two arches (Fig.1).

Since the tooth wear lesions are bacteria free, it is important to keep in mind that these lesions could be associated with carious disease and that 'ultra-conservative' treatment may require the use of additional protocols focused on patient benefits.

Finally, it has been shown that certain lesions are the direct consequence of eating disorders, obsessive compulsive disorders (OCD), stress and gastro-oesophageal reflux disease (GORD), which require combined medical and dental intervention. ${ }^{5}$ Tooth wear lesions can also be associated with bruxism phenomena. ${ }^{6}$

Ultraconservative treatment should include:

- Maximum preservation of remaining dental structures

- Future therapeutic intervention under the same conditions (repair, replacement)

- Control of aetiological factors

- Treatment of any general systemic factors by a medical team. 
It is important to recall that this subject does not have a simple methodological approach involving specific restoration techniques.

More precisely it involves a global attitude of the clinician, resulting from a good knowledge of aetiopathological factors allowing early diagnosis, recall, protection, stabilisation, temporisation, interception before undertaking specific restorative procedures in selected cases. This clinical approach is a good example of what we call in France 'médecine bucco-dentaire' and in Switzerland 'médecine dentaire' (dental medicine)

\section{EARLY DIAGNOSIS}

Nowadays it is usual to detect early proximal caries by retrocoronal X-ray. Detailed examinations of caries predilection sites are well documented. The process allowing early identification of erosive and abrasive lesions is generally poorly applied, as it remains controversial and more often associated with identifying one or more risk factors. Early erosive and abrasive lesions are normally asymptomatic with the exception of cervical buccal lesions, which can cause hypersensitivity symptoms. In fact, the early lesions remain an enamel defect without any symptomology. Yet early diagnosis is the best method in eliminating causative factors at this early stage whether they originate from alimentation, traumatic brushing or a systemic pathology. The diagnostics tools available are far less sophisticated than those available for the early detection of initial caries such as laser fluorescence, and only eye and practitioner's determination are essential.

\section{EXAMINATION SCREENING}

Actually, the trained eye of the practitioner remains the main way for early diagnosis. However, it requires a good knowledge of initial tooth wear sites and of the medical context. While it is simple to recognise an established tooth wear lesion, early lesions often escape from a usual clinical exam focused on caries.

Drying the teeth before observation is required in the same way as dental caries. The main sites to observe are:

- The cusp tops for cup lesions (Fig. 2)

- The buccal surfaces of the maxillary teeth to reveal early tooth wear lesions by depressing surrounding gums (Fig.3)

- The buccal surfaces of the anterior maxillary teeth for early tooth wear lesions of extrinsic nature (Fig.4)

- The lingual surfaces of the anterior maxillary region around the cingulum are characteristic of intrinsic erosion (Fig. 5).

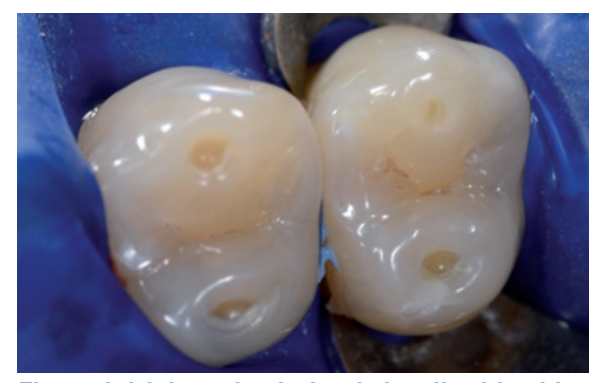

Fig. 2 Initial erosive lesion is localized in this typical case on the cusp tops of posterior teeth with 'cup' lesion

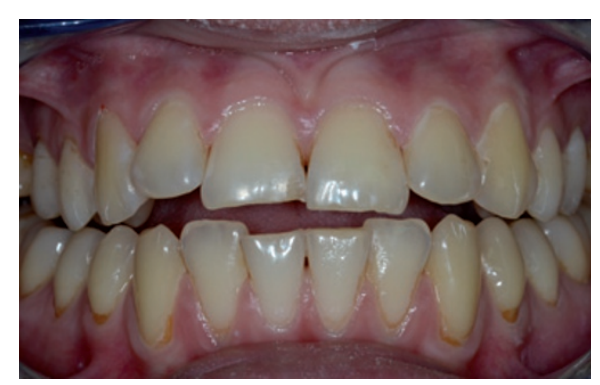

Fig. 3 Clinical exam highlights several initial cervical erosive lesions for this young patient with anorexia

A sextant exam can be used to apply the BEWE classification criteria (Tables 1 and 2), ${ }^{7}$ which provides a reference for following examinations. This classification is simple enough for daily use of a general practitioner. It is also possible that pre-identified risk factors will guide the dental exam. Table 3 is based on clinical observations involving around 200 patients who presented for a specialised consultation focused on eating disorders. It could be a help for a general practitioner to guide the initial clinical exam.

The ultimate aim of early diagnosis is to formulate a recall strategy, identification of aetiological factors and eliminating them wherever possible and finally to intercept with measures designed to protect dental tissues.

Other diagnostic tools are of limited use. However, plaster cast models allow assessment of quantitative substance loss and provide an objective future reference.

Macro photos, if available, also permit objective assessment to follow lesion development and motivate the patient to modify harmful habits.

\section{PREVENTION, INTERCEPTION, PROTECTION, TEMPORISATION}

\section{Initial lesions}

Erosive lesions not requiring debridement of pathological dental tissues should be approached with strictly ultraconservative measures. It just remains to determine the optimum adapted treatment planning involving a combination of prevention, interception,

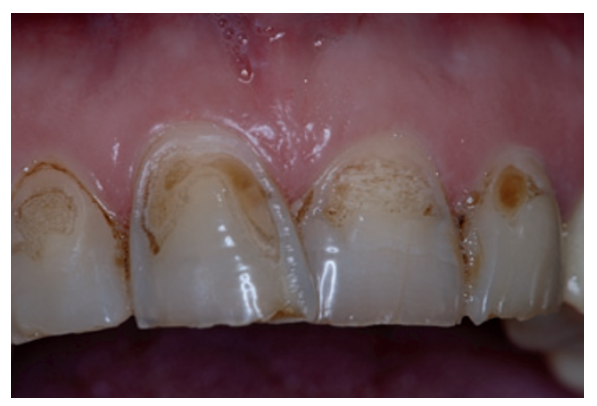

Fig. 4 Extrinsic erosion lesions are preferably localised on buccal side of maxillary incisors

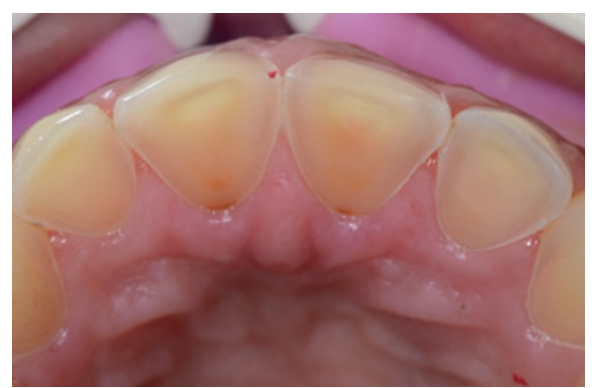

Fig. 5 Reflux from vomiting lead to acidic dissolution of the lingual side of maxillary incisors

protection, temporisation and restoration if necessary. The treatment plan corresponds to the BEWE score (Tables 1 and 2).

Important patient recommendations include a suitable brushing method, the use of an electric toothbrush that stops when excessive pressure is applied and the use of specific mouthwashes and toothpastes even in the current absence of sufficient supporting clinical studies proving effectiveness (Fig. 6). ${ }^{9}$

Resin trays containing fluorinated gels can reduce sensitivity without any effect on lesion development. However, patients presenting with caries free lesions can also have an increased risk of developing caries, in particular in the case of anorexia and bulimia. It is therefore good practice to undertake an overall risk assessment and not to focus solely on the most obvious (Fig. 7). ${ }^{10}$

Ideally, dental surfaces should be isolated from an aggressive acid environment by using a layer of adhesive resin. However, avoiding proximal overloading when using this type of material requires a delicate touch and the low strength of these resins significantly limits their period of effectiveness. Nevertheless, the use of the recently available 4-meta resin (Bondfill $\mathrm{SB}^{\circledR}$ Sun medical) appears promising, based on a personal evaluation of its effectiveness in 15 severe cases. The material remains in place three months after application and sensitivities have not reappeared. The short setting time only allows one or two teeth to be treated in the same time. This resin layer, which can be compared to Superbond ${ }^{\circledR}$, but 


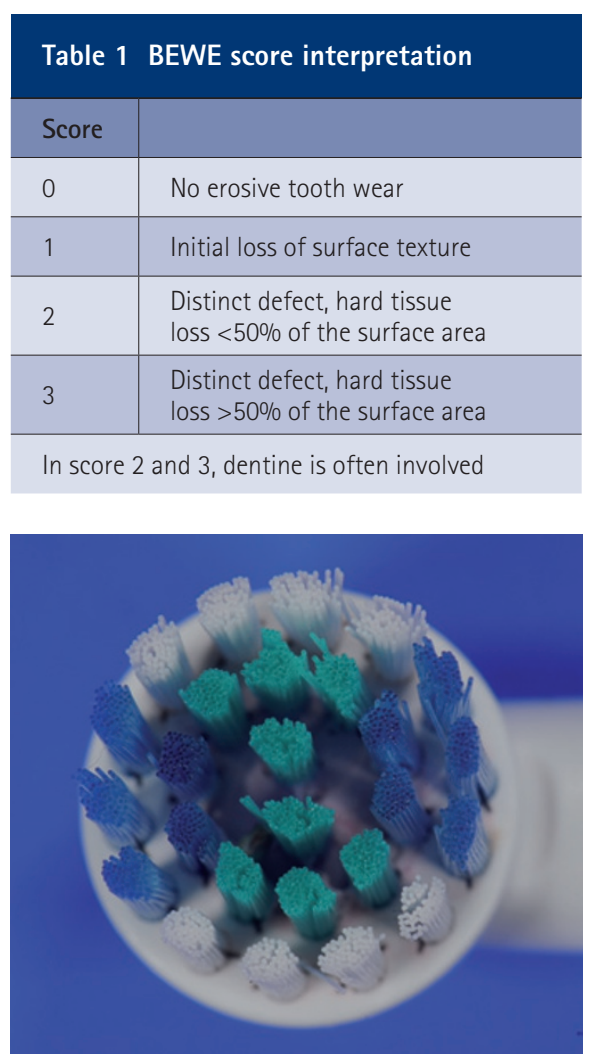

Fig. 6 The use of an electric toothbrush reduces abrasion phenomena especially if damage is associated to the pressure

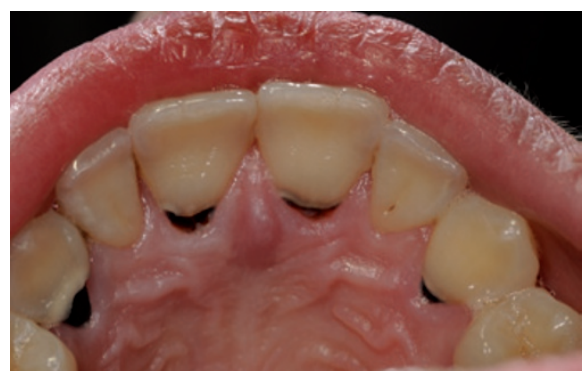

Fig. 7 Unusual cervical caries lesions localised on anterior teeth are linked to sugary food before vomiting. (Patient with anorexia and bulimia)

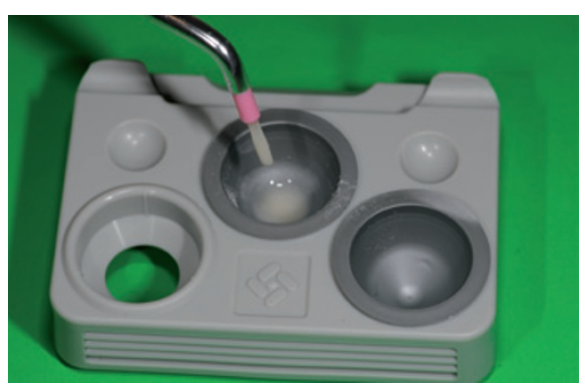

Fig. 8 Use of a specific resin (Bondfill $\mathrm{SB}^{\circledR}$

Sun medical) is a good way to protect exposed dentinal surfaces and to remove sensitivity

reinforced by organic fillers, ${ }^{11}$ is an effective bonding agent allowing, if indicated, a conventional direct or indirect adhesive procedure (Fig. 8).

Given that the systematic restoration of substance loss resulting from tooth wear

\begin{tabular}{|c|c|c|}
\hline $\begin{array}{l}\text { Cumulative score } \\
\text { of all sextants }\end{array}$ & \begin{tabular}{|l|} 
Risk \\
level
\end{tabular} & Management \\
\hline$\leq 2$ & None & $\begin{array}{l}\text { Routine maintenance and observation } \\
\text { Repeat at three-year intervals }\end{array}$ \\
\hline 3-8 & Low & $\begin{array}{l}\text { Oral hygiene and dietary assessment, and advice, routine maintenance and } \\
\text { observation } \\
\text { Repeat at two-year interval review and maintenance }\end{array}$ \\
\hline $9-13$ & Medium & $\begin{array}{l}\text { Oral hygiene and dietary assessment, and advice. Identify the main } \\
\text { aetiological factor(s) for tissue loss and develop strategies to eliminate } \\
\text { respective impacts. } \\
\text { Consider fluoridation measures or other strategies to increase the resistance } \\
\text { of tooth surfaces } \\
\text { Ideally, avoid the placement of restorations and monitor erosive wear with } \\
\text { study casts, photographs, or silicone impressions } \\
\text { Repeat at } 6-12 \text { month intervals }\end{array}$ \\
\hline$\geq 14$ & High & $\begin{array}{l}\text { Oral hygiene and dietary assessment, and advice. Identify the main } \\
\text { aetiological factor(s) for tissue loss and develop strategies to eliminate } \\
\text { respective impacts } \\
\text { Consider fluoridation measures or other strategies to increase the resistance } \\
\text { of tooth surfaces } \\
\text { Ideally, avoid the placement of restorations and monitor erosive wear with } \\
\text { study casts, photographs, or silicone impressions } \\
\text { Especially in cases of severe progression consider special care that may } \\
\text { involve restorations } \\
\text { Repeat at 6-12 month intervals }\end{array}$ \\
\hline
\end{tabular}

\section{Table 3 Relation between clinical and aetiology signs of the erosive and abrasive lesions}

\begin{tabular}{|c|c|c|c|c|c|}
\hline Aetiology & Main site & Secondary site & $\begin{array}{l}\text { Lesion } \\
\text { appearance }\end{array}$ & Sensitivity & $\begin{array}{l}\text { Periodontal } \\
\text { appearance }\end{array}$ \\
\hline $\begin{array}{l}\text { Extrinsic erosion } \\
\text { of alimentary } \\
\text { origin }\end{array}$ & $\begin{array}{l}\text { Buccal surfaces } \\
\text { of anterior } \\
\text { maxillary teeth. } \\
\text { Cervical areas } \\
\text { of anterior } \\
\text { mandibular and } \\
\text { maxillary teeth. }\end{array}$ & $\begin{array}{l}\text { Buccal surface } \\
\text { of anterior } \\
\text { mandibular } \\
\text { teeth } \\
\text { Cusp points } \\
\text { of mandibular } \\
\text { teeth }\end{array}$ & $\begin{array}{l}\text { poorly defined } \\
\text { margins, saucer } \\
\text { shape }\end{array}$ & $\begin{array}{l}\text { Yes if cervical } \\
\text { dentine is } \\
\text { exposed }\end{array}$ & $\begin{array}{l}\text { Good with } \\
\text { sometimes } \\
\text { early radicular } \\
\text { exposure }\end{array}$ \\
\hline $\begin{array}{l}\text { Abrasion as } \\
\text { a result of } \\
\text { traumatic } \\
\text { brushing }\end{array}$ & $\begin{array}{l}\text { Buccal cervical } \\
\text { areas of } \\
\text { maxillary teeth } \\
\text { especially } \\
\text { premolars }\end{array}$ & $\begin{array}{l}\text { Buccal cervical } \\
\text { areas of } \\
\text { mandibular } \\
\text { teeth especially } \\
\text { premolars }\end{array}$ & $\begin{array}{l}\text { Wedge shape } \\
\text { lesion }\end{array}$ & $\begin{array}{l}\text { Mainly on } \\
\text { initial lesions } \\
\text { formation of } \\
\text { sclerotic dentine } \\
\text { is following. }\end{array}$ & $\begin{array}{l}\text { Good with a } \\
\text { high level of } \\
\text { keratinised gum }\end{array}$ \\
\hline $\begin{array}{l}\text { Erosion caused } \\
\text { by G.O.R.D. }\end{array}$ & $\begin{array}{l}\text { Occlusal } \\
\text { surfaces of } \\
\text { mandibular } \\
\text { molars. } \\
\text { Cusp points } \\
\text { of mandibular } \\
\text { molars. }\end{array}$ & $\begin{array}{l}\text { Buccal surfaces } \\
\text { of mandibular } \\
\text { molars. } \\
\text { Cusp points } \\
\text { of maxillary } \\
\text { molars. } \\
\text { Lingual surfaces } \\
\text { of the anterior } \\
\text { maxillary teeth; }\end{array}$ & $\begin{array}{l}\text { Concave lesions } \\
\text { starting on the } \\
\text { cusp points; }\end{array}$ & $\begin{array}{l}\text { Yes, mainly } \\
\text { during } \\
\text { mastication in } \\
\text { case of dentine } \\
\text { exposure }\end{array}$ & $\begin{array}{l}\text { Good, but } \\
\text { with radicular } \\
\text { exposure in } \\
\text { affected areas } \\
\text { by erosion from } \\
\text { frequent reflux }\end{array}$ \\
\hline $\begin{array}{l}\text { Erosion caused } \\
\text { by anorexia/ } \\
\text { bulimia }\end{array}$ & $\begin{array}{l}\text { Lingual surfaces } \\
\text { of maxillary } \\
\text { canines and } \\
\text { incisors }\end{array}$ & $\begin{array}{l}\text { Lingual surfaces } \\
\text { of maxillary } \\
\text { molars and } \\
\text { premolars. } \\
\text { Occlusal } \\
\text { surfaces of } \\
\text { premolars and } \\
\text { molars }\end{array}$ & $\begin{array}{l}\text { Incisors: } \\
\text { Progressive } \\
\text { form alteration } \\
\text { of the lingual } \\
\text { side relief. } \\
\text { Poorly defined } \\
\text { shape lesions of } \\
\text { posterior teeth }\end{array}$ & $\begin{array}{l}\text { Fickle but can } \\
\text { be severe if } \\
\text { dentine surface } \\
\text { is exposed }\end{array}$ & $\begin{array}{l}\text { Frequent } \\
\text { radicular } \\
\text { surfaces } \\
\text { exposed }\end{array}$ \\
\hline Attrition & $\begin{array}{l}\text { Premolar and } \\
\text { molar cusps and } \\
\text { incisal wedge of } \\
\text { anterior teeth of } \\
\text { the two arches }\end{array}$ & $\begin{array}{l}\text { Marginal ridge } \\
\text { and lingual } \\
\text { surfaces of } \\
\text { the anterior } \\
\text { maxillary teeth }\end{array}$ & $\begin{array}{l}\text { Flat surfaces } \\
\text { Scratches are } \\
\text { sometimes } \\
\text { present }\end{array}$ & $\begin{array}{l}\text { No, if dentine } \\
\text { exposed. } \\
\text { Sclerotic dentine } \\
\text { formation }\end{array}$ & $\begin{array}{l}\text { No mobility } \\
\text { Healthy } \\
\text { periodontal } \\
\text { tissues }\end{array}$ \\
\hline
\end{tabular}

lesions is not routine, a non-invasive restoration procedure should be applied if risk factors have not been eliminated. This is especially the situation in severe case of anorexia, bulimia and persistent gastrointestinal reflux. Initial erosive lesions situated on the cusp tops require limited restorations but for large defects complete 

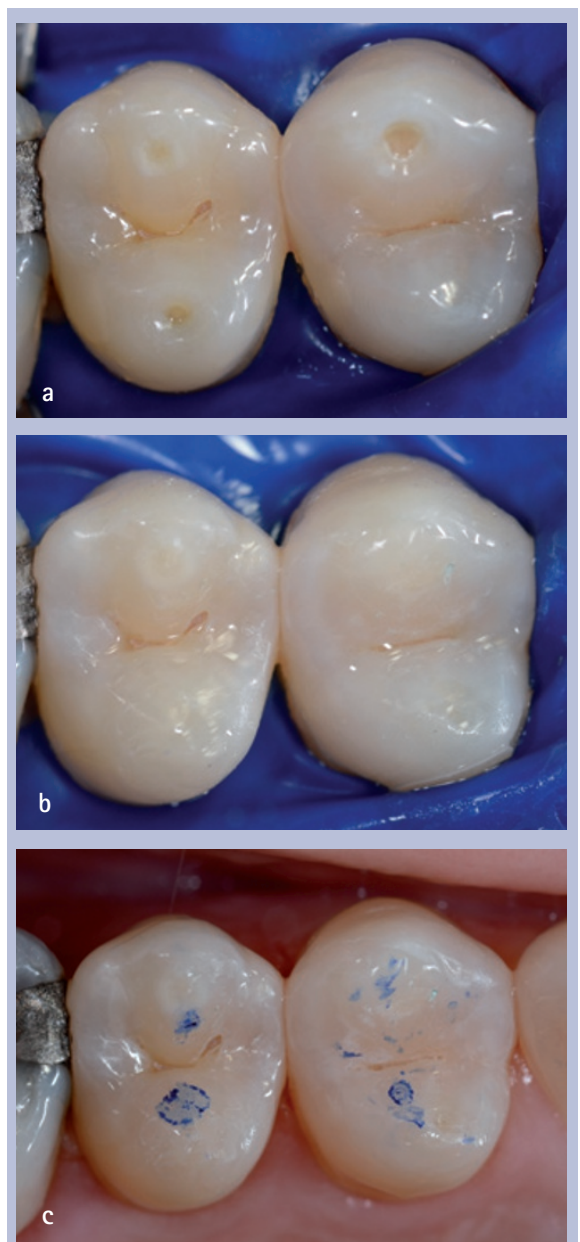

Fig. 9 Interceptive treatment of cup lesions localised on the top of cusps. a) Initial situation; b) direct composite restoration; c) bite control with articulating paper
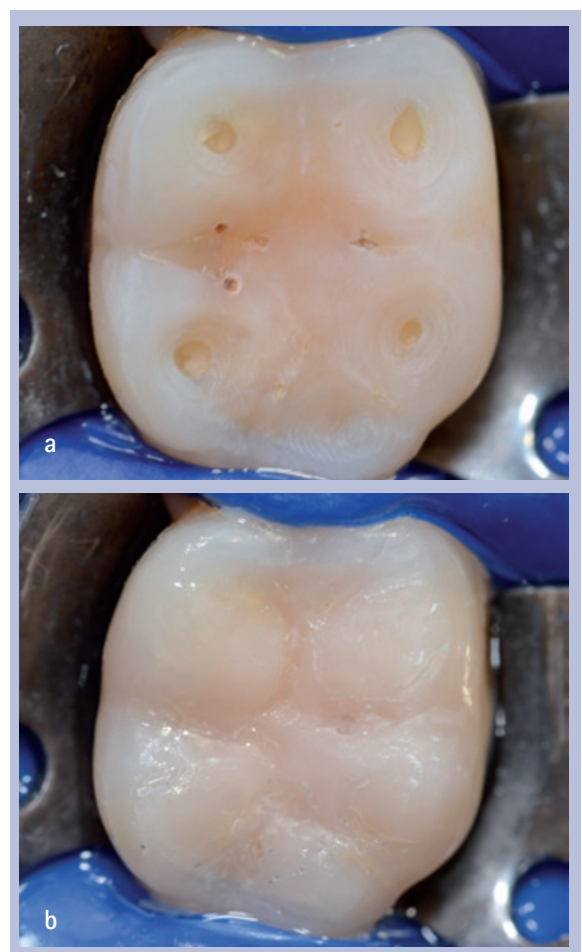

Figs $10 \mathrm{a}$ and $\mathrm{b}$ Restoration of an occlusal surface without any invasive procedure (Sonicfill ${ }^{\circledR}$ composite Kerr)

\begin{tabular}{|c|c|c|}
\hline Category & Substance loss & Treatment options* \\
\hline Group 1 & $\begin{array}{l}\text { Superficial, enamel (crown), dentine } \\
\text { (root) }\end{array}$ & $\begin{array}{l}\text { Advice and prophylactic measures } \\
\text { Restoration contra-indicated }\end{array}$ \\
\hline Group 2 & $\begin{array}{l}\text { Moderate and isolated, enamel and } \\
\text { dentine. } \\
\text { No functional disability }\end{array}$ & $\begin{array}{l}\text { Direct adhesive restoration } \\
\text { Periodontal treatments for radicular exposure }\end{array}$ \\
\hline Group 3 & $\begin{array}{l}\text { intermediate affecting a group of } \\
\text { teeth without functional disability }\end{array}$ & $\begin{array}{l}\text { Direct or indirect adhesive restoration } \\
\text { Periodontal rehabilitation often required }\end{array}$ \\
\hline $\begin{array}{l}\text { Group } 4 \\
\text { (4a and } 4 b)\end{array}$ & $\begin{array}{l}\text { Severe and multiple deterioration } \\
\text { of articular relationship without } \\
\text { TMJ disorder } \\
\text { Without (4a) or with (4b) loss of } \\
\text { vertical dimension }\end{array}$ & $\begin{array}{l}\text { Restoration of a balanced and functional occlusal } \\
\text { relationship } \\
\text { Direct and indirect adhesive restorations, } \\
\text { prosthodontics. without or with increasing vertical } \\
\text { dimension. }\end{array}$ \\
\hline $\begin{array}{l}\text { Group } 5 \\
\text { (5a and } 56 \text { ) }\end{array}$ & $\begin{array}{l}\text { Severe and generalized, loss of } \\
\text { articular relationship with TMJ } \\
\text { disorders without (5a) or with (5b) loss } \\
\text { of vertical dimension }\end{array}$ & $\begin{array}{l}\text { Total oral rehabilitation of two arches in } 2 \text { stages: } \\
\text { 1. Adhesive reconstruction of two arches to recover } \\
\text { function and aesthetic. } \\
\text { 2. Prosthodontic treatment sometimes with implants } \\
\text { 5a. without increasing vertical dimension } \\
\text { 5b. increasing vertical dimension }\end{array}$ \\
\hline
\end{tabular}

"Monitoring is required if erosion is detected, advices are always included in treatment planning

protection of the occlusal surfaces could be required (Fig. 9).

\section{RESTORATIVE TREATMENT (BASED ON SPECIFIC REQUIREMENTS)}

Substance loss coming from toothwear can lead to functional, aesthetic or even psychological problems. Large, isolated lesions may require restoration by using a combination of procedures of adhesive dentistry (Fig. 10). In contrast, widespread lesions can indicate complex rebuilding of the two arches. There are few available recommendations on the best treatment approach and only case reports exists. ${ }^{12}$ It is therefore reasonable to suggest a specific treatment plan for each clinical situation encountered in Table $4 .{ }^{13}$

It could be surprising to discuss large occlusal restorations in a paper devoted to minimal invasive procedures. However, the choice of treatment procedure should remain strictly non-invasive by the direct or indirect adhesion of composites. Certain scenarios will require prosthetic treatment at a later state. Yet, faced with aetiological factors, which are difficult or impossible to control, this intervention should be treated as a long-term interceptive treatment contributing to improved oral health of the patient. ${ }^{14}$ It is inaccurate to assume that a perfectly adapted procedure has to be detailed for each clinical situation. Nevertheless, a certain number of useful guidelines can be followed based on knowledge of biomaterials and of clinical situations. There is no evidence based in this area and only case reports exist.

\section{Nature of exposed dental tissues governing the choice of adhesive systems}

A slightly permeable sclerotic dentine can be
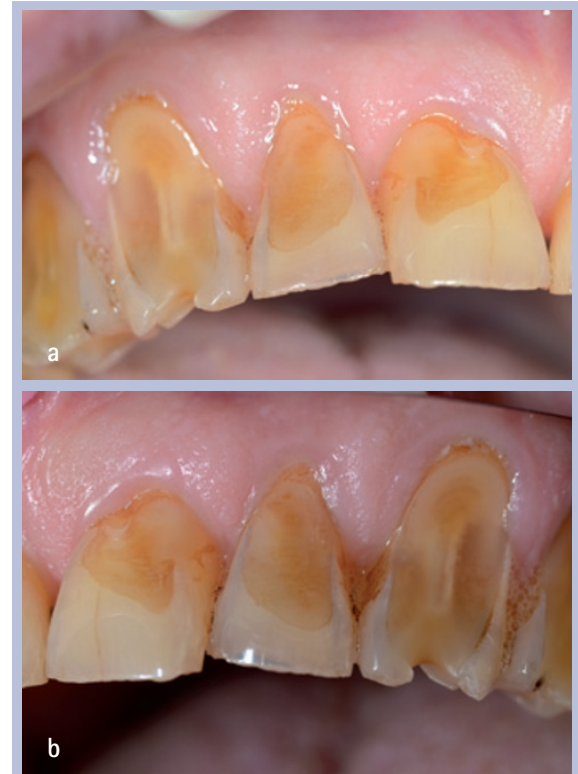

Figs $11 \mathrm{a}$ and $\mathrm{b}$ Erosions consecutive to gastro esophageal reflux (GORD), acidic food and a traumatic tooth brushing. Patient is 70 years old. All teeth have a healthy pulp

identified by its often smooth surface without sensitivity when an air jet is applied during clinical examination. The use of an etch and rinse system for bonding is justified, provided that contamination of dental surfaces by buccal fluids during the adhesion process is avoided. It is essential to have a sealed operating field as the rubber dam. Adhesive systems require two steps (etch and rinse two steps) or three (etch and rinse three steps) if the promoter and the adhesive resin are separated. The etch and rinse three steps remains the gold standard in terms of adhesion. ${ }^{15}$

A permeable dentine regularly exposed to acids, as occurs in erosion, is characterised 

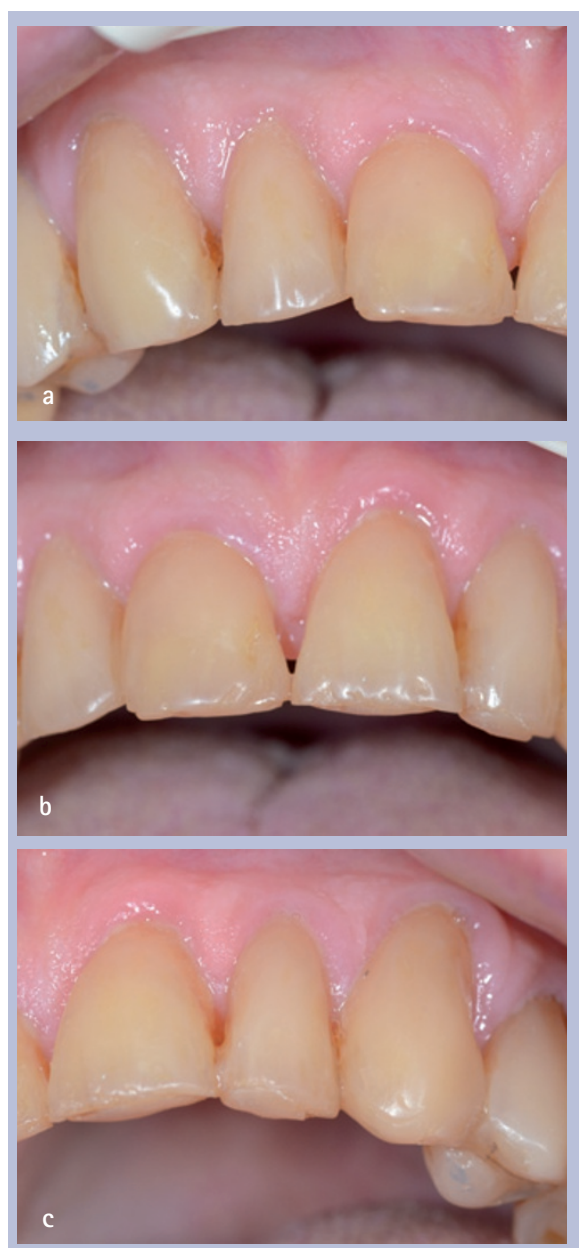

Figs $12 \mathrm{a}-\mathrm{c}$ Restorative treatment of the previous clinical case with a direct composite (Kalore ${ }^{\circledR} \mathrm{GC}$ )

by a matt appearance, stained by exogenous colourants and display sensitivity when exposed to air from a syringe. This superficial dentine is partially demineralised suffering from a type of chronic etching effect. Under these conditions it would seem advantageous to use a self-etching system, preferably two steps systems, which have clearly been identified as superior in the international literature. ${ }^{16}$

\section{Selection criteria and composite application}

Composite resins have seen improvement in both their aesthetic and physical properties in recent years. Namely polymerisation shrinkage has been reduced to $2 \%$ in a good number of cases, colour stability has been improved, polishing ability is satisfactory even if the long-term results remains a weak point. The major benefits of these materials are:

- Re-intervention is possible by adding or removing material

- Possibility of using a direct technique to apply a thin layer of material

- Possibility to use direct and indirect techniques on the same tooth.
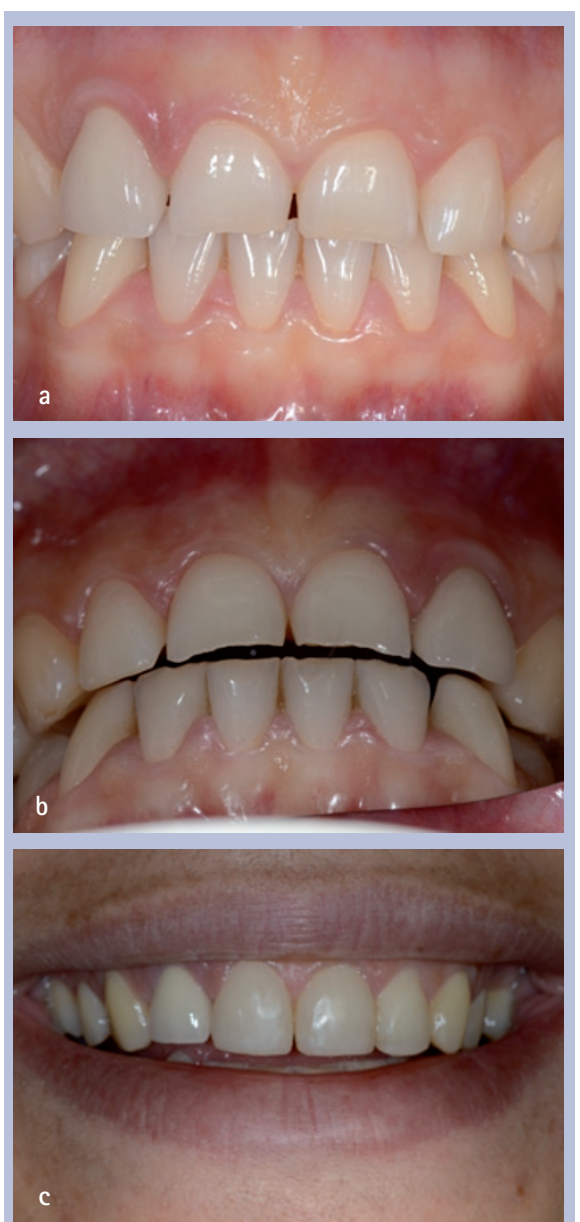

Figs 13a-c Combination of direct and indirect adhesive restorations of anterior teeth of a patient with anorexia and bulimia. a) Initial situation in occlusion;

b) The space available for lingual veneers is evaluated in the centric position; c) Aesthetic result after the placement of direct composite restoration on the buccal side. As a reference, the ceramic crown on the lateral incisor has been preserved. Indirect composite material: Premise indirect ${ }^{\circledR}$ Kerr, Direct composite material: Venus Diamond ${ }^{\circledR}$ Heraeus

Figures 11 and 12 represent the case of a patient wishing to conserve teeth damaged by abrasive and erosive processes resulting from gastro-oesophageal reflux and nutritional causes. Vitality testing revealed a healthy pulp for all teeth. Only prosthetic ceramic crowns and post and core restorations were suggested. A combination of an opaque and two coloured micro-hybrid composites (GC Kalore 0A3, A3.5, A3) results in the preservation of essential dental tissues and an acceptable aesthetic outcome. A direct technique was used as the sole intervention to avoid all cavity preparation.

A combination of indirect and direct techniques for the same tooth has been well documented. It is possible to apply a combination of ceramic veneers with lingual composites on anterior teeth. In cases of

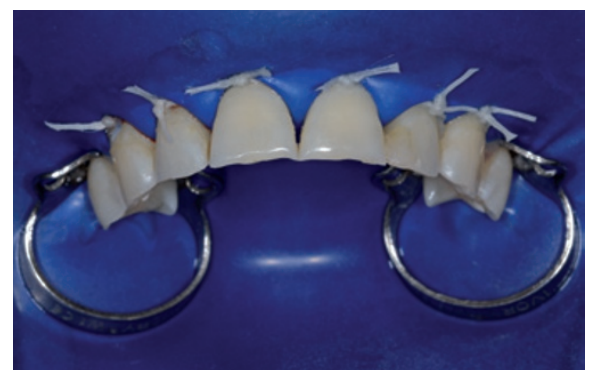

Fig. 14 The rubber dam remains the best way to preserve the long-term behaviour of adhesive restorations

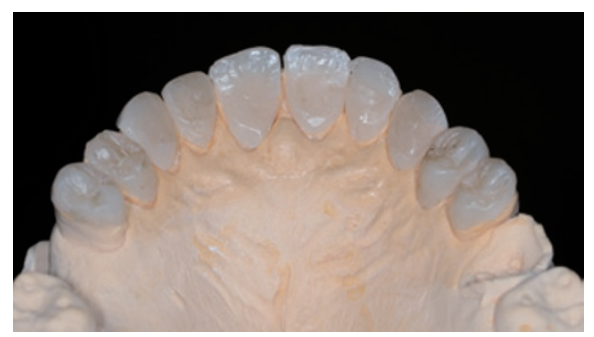

Fig. 15 It is quite easy to build indirect composite restorations on a model without any dental preparation. However, a depth of $0.8 \mathrm{~mm}$ is required (Majesty posterior ${ }^{\circledR}$ Kuraray, shade A3)

severe eating disorders, bruxism is often associated with erosive and abrasive factors. An alternative approach is to apply a direct vestibular composite resin, ${ }^{14}$ giving a careful interception solution (Fig. 13) Composite elements can therefore be elaborated from conventional laboratory composites (Premise ${ }^{\circledR}$ indirect Kerr) or with especially resistant direct composite (Majesty ${ }^{\circledR}$ posterior Kuraray). The indirect adhesion procedure is simple provided that the operating field is correctly placed (Fig.14). The laboratory work is equally simple wherever these elements are not visible and do not extend proximally. Figure 15 illustrates mono shade construction (A3 Majesty ${ }^{\circledR}$ posterior Kuraray) undertaken at the same time as addressing the occlusal surfaces of the premolars. The cast plaster model is not prepared, only a specific varnish is applied. The aesthetic result is achieved when a final layer of composite is applied to buccal surfaces with the lingual veneers supporting the aesthetic reconstruction.

Presently, it seems surprising that these clinical restoration procedures require further development. However, given the prevalence of tooth wear lesions, future research should strive to provide non-invasive, cost effective and aesthetic solutions.

Therefore there is no unique solution but instead a treatment plan that systematically aims to preserve bacteria-free tissues in contrast to carious tissue. Finally when the aetiopathological factors are uncontrolled future re-intervention must be considered before a decision is made. 
The authors would like to thank Claudie DamourTerrasson, publishing director of the Groupe Information Dentaire, Paris France, for the authorisation of translation and publication of the series in the BDJ; Dr Avijit Banerjee for his support.

1. Lussi A, Hellwig E, Ganss C, Jaeggi T. Dental erosion. Oper Dent 2009; 34: 251-262.

2. Lussi A. Dental erosion. From diagnosis to therapy. Bâle: Karger, 2006

3. Arnadottir I B, Holbrook W P, Eggertsson $\mathrm{H}$ et al. Prevalence of dental erosion in children: a national survey. Community Dent Oral Epidemiol 2010; 38: 521-526.

4. El Aidi H, Bronkhorst E M, Truin G J. A longitudinal study of tooth erosion in adolescents. J Dent Res 2008; 87: 731-735.

5. Lo Russo L, Campisi G, Di Fede O, Di Liberto C, Panzarella V, Lo Muzio L. Oral manifestations of eating disorders: a critical review. Oral Dis 2008; 14: 479-484.
6. Ohmure H, Oikawa K, Kanematsu K et al. Influence of experimental esophageal acidification on sleep bruxism: a randomized trial. J Dent Res 2011 . 90: 665-671.

7. Brandini D A, Pedrini D, Panzarini S R, Benete I M, Trevisan C L Clinical evaluation of the association of non-carious cervical lesions, parafunctional habits, and TMD diagnosis. Quintessence Int 2012; 43: 255-262.

8. Bartlett D, Gans C, Lussi A. Basic Erosive Wear Examination (BEWE) a new scoring system for scientific and clinical needs. Clin Oral Invest 2008; 12: 15-19.

9. Wang $X$, Megert B, Hellwig E, Neuhaus K W, Lussi A Preventing erosion with novel agents. J Dent 2011; 39: 163-170.

10. Colon P. Atteintes dentaires consécutives à I'anorexie: quelle attitude préventive? Inf Dent 2011; 30: 31-33.

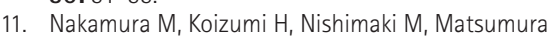
H. Clinical application of a tri-n-butylborane initiated adhesive resin filled with prepolymerized composite particles. Asian Pac J Dent 2011;

11: 61-65.

12. Kelleher M G, Bomfim D I, Austin R S. Biologically based restorative management of tooth wear. Int J Dent 2012; 2012: 742, 509.

13. Lasfargues J J, Colon P. Odontologie conservatrice restauratrice: une approche médicale globale Tome 1. Paris: Ed CdP, 2010.

14. Colon P, Lecorre A. Traitement conservateur des destructions dentaires non carieuses. Real Clin 2005; 16: 53-62.

15. Ryou H, Niu L N, Dai L et al. Effect of biomimetic remineralization on the dynamic nanomechanical properties of dentin hybrid layers. J Dent Res 2011; 90: 1122-1128.

16. Vanajasan P. Dhakshinamoorthy M, Subba Rao C V. Factors affecting the bond strength of self-etch adhesives: a meta-analysis of literature. $J$ Conserv Dent 2011; 14: 62-67. 